\title{
Pengaruh Kepemimpinan, Motivasi Dan Budaya Kerja Terhadap Kinerja Karyawan Pada PT. Ambassador Zulias Kabupaten Wajo
}

\author{
Andi Muchlis Sirajuddin', Abdul Rahman Mus² \& Aryati Arfah ${ }^{3}$ \\ 1,2,3Magister Manajemen, Universitas Muslim Indonesia. \\ ${ }^{1}$ Koresponden Penulis, E-mail: andyssirajuddin@gmail.com
}

\begin{abstract}
ABSTRAK
Penelitian ini dilakukan dengan tujuan untuk: (1). menganalisis Pengaruh kepemimpinan terhadap kinerja karyawan PT. Ambassador Zulias Kab. Wajo. (2). menganalisis Pengaruh motivasi terhadap kinerja karyawan PT. Ambassador Zulias Kab. Wajo. (3). menganalisis Pengaruh budaya kerja terhadap kinerja karyawan PT. Ambassador Zulias Kab. Wajo Sampel yang digunakan dalam penelitian ini adalah Karyawan PT. Ambassador Zulias Kab. Wajo sebanyak 32 orang. Hasil penelitian ini menunjukkan bahwa: (1) Hasil penelitian menunjukkan bahwa variable Kepemimpinan (X1) berpengaruh positif dan signifikan terhadap kinerja karyawan. (2) variabel Motivasi (X2) berpengaruh secara negatif dan tidak signifikan terhadap kinerja karyawan. (3) variabel Budaya Kerja (X3) berpengaruh secara negatif dan tidak signifikan terhadap kinerja karyawan.
\end{abstract}

Kata kunci: Kepemimpinan, Motivasi, Budaya Kerja, Kinerja Karyawan

\begin{abstract}
This research was conducted with the aim to: (1). analyze the effect of leadership on the performance of employees of PT. Ambassador Zulias Kab. Wow. (2). analyze the effect of motivation on the performance of employees of PT. Ambassador Zulias Kab. Wow. (3). analyze the effect of work culture on the performance of employees of PT. Ambassador Zulias Kab. Wajo. The sample used in this study was PT. Ambassador Zulias Kab. Wajo as many as 32 peopletThe results of this study indicate that: (1) The results of the study indicate that the Leadership variable (X1) has a positive and significant effect on employee performance. (2) Motivation variable (X2) has a negative and insignificant effect on employee performance. (3) Work Culture variable (X3) has negative and insignificant effect on employee performance.
\end{abstract}

Key Words: Leadership, Motivation, Work Culture, Employee Performance. 


\section{PENDAHULUAN}

Sumber Daya Manusia merupakan faktor penting dalam suatu organisasi atau perusahaan. Agar aktivitas manajemen berjalan dengan baik, perusahaan harus memiliki karyawan yang berpengetahuan dan berketerampilan tinggi serta usaha untuk mengelola perusahaan seoptimal mungkin sehingga kinerja karyawan meningkat.

Upaya untuk meningkatkan kualitas SDM ini, utamanya sumber daya manusia perusahaan perlu diperlakukan dengan baik, terarah, dan terencana sehingga perusahaan pun dapat bersaing secara sehat dengan perusahaan lain, mengingat kedepan persaingan antara perusahaan akan semakin ketat.

Sumber daya manusia merupakan salah satu hal yang mendapat perhatian serius, tanpa sumber daya manusia yang berkualitas kemajuan suatu daerah tidak akan terjadi. (Hasibuan, 2015) menyatakan bahwa sumber daya manusia menjadi unsur pertama dan utama dalam setiap aktivitas yang dilakukan. Peralatan yang canggih tanpa adanya peran aktif SDM tidak berarti apa-apa.

Kepemimpinan merupakan faktor yang menentukan dalam suatu perusahaan. Berhasil atau gagalnya perusahaan dalam mencapai suatu tujuan dipengaruhi oleh cara seorang pemimpin. Sosok pemimpin dalam perusahaan dapat menjadi efektif apabila pemimpin tersebut mampu mengelola perusahaannya dan mempengaruhi perilaku bawahan agar mau bekerja sama dalam mencapai tujuan perusahaan. Berikut ini merupakan definisi kepemimpinan yang dikemukakan oleh beberapa ahli: (Sutikno, 2014) "Kepemimpinan dalam organisasi diarahkan untuk mempengaruhi orang-orang yang dipimpinnya, agar mau berbuat seperti yang diharapkan ataupun diarahkan oleh orang lain yang memimpinnya. Veithzal Rivai (2013) mengemukakan bahwa: "Kepemimpinan adalah suatu perilaku dengan tujuan tertentu untuk mempengaruhi aktivitas para anggota kelompok untuk mencapai tujuan bersama yang dirancang untuk memberikan manfaat individu dan organisasi, sehingga dalam suatu organisasi kepemimpinan merupakan faktor yang sangat penting dalam menentukan pencapaian tujuan yang telah ditetapkan oleh organisasi". Katz dan Kahn dalam (Priatna (2015) berpendapat: "Kepemimpinan adalah peningkatan pengaruh sedikit demi sedikit berada diatas kepatuhan mekanis terhadap pengarahan-pengarahan rutin organisasi."Berdasarkan semua pengertian yang telah dikemukakan para ahli diatas, maka dapat diambil kesimpulan bahwa kepemimpinan adalah proses dan perilaku seorang pemimpin dalam mempengaruhi perilaku dan mendayagunakan para bawahannya agar mau bekerja sama dalam melaksanakan tugas dan tanggung jawab untuk mencapai tujuan perusahaan.

Keberhasilan suatu organisasi baik sebagai keseluruhan maupun berbagai kelompok dalam suatu organisasi tertentu, sangat tergantung pada efektivitas kepemimpinan yang terdapat dalam organisasi yang bersangkutan, seorang pemimpin harus dapat menciptakan hubungan kerja yang harmonis, baik antara sesama karyawan, maupun antara atasan dengan bawahan. Kemampuan pemimpin dalam mengarahkan serta mengkoordinasikan potensi yang dimiliki seluruh karyawan akan terkait dengan peningkatan motivasi dalam melakukan pekerjaan. Salah satu masalah yang menarik untuk dikaji berkaitan dengan pencapaian tujuan suatu perusahaan adalah mengenai kinerja karyawan. 
Kondisi kerja karyawan PT. Ambassador Zulias Kab.Wajo belum tertanamnya dijiwa karyawannya untuk melaksanakan tugas dengan inisiatif sendiri, karyawan melaksanakan tugasnya dengan menunggu perintah terlebih dahulu dari atasan Hal ini mengakibatkan standar kerja yang kurang efektif belum maksimal tercapai. Potensi yang dimiliki karyawan PT. Ambassador Zulias Kab.Wajo belum dapat menemukan standar kerja yang baik dikarenakan masih kurangnya pengarahan, bimbingan dan komunikasi antara atasan dan bawahan.

Hasil penelitian yang dilakukan oleh Waode Zusnita Muizu, Umi Kaltum dan Ernie T. Sule, (2019), kepemimpinan dan motivasi kerja berpengaruh positif dan signifikan terhadap kinerja karyawan.

Motivasi merupakan sesuatu yang menimbulkan semangat atau dorongan kerja. Dalam kinerja karyawan agar seseorang lebih semangat lagi perlu adanya motivasi dalam bekerja. Tetapi motivasi bukan merupakan satu-satunya agar kinerja karyawan baik. Dengan adanya motivasi, maka terjadilah kemauan kerja dan dengan adanya kemauan untuk bekerja serta dengan adanya kerja sama, maka kinerja akan meningkat. Persoalan dalam memotivasi karyawan tidak mudah karena dalam diri karyawan terdapat keinginan, kebutuhan dan harapan yang berbeda antara satu karyawan dengan karyawan lain. Maka apabila perusahaan dapat memahami persoalan motivasi kerja dan mengatasinya maka perusahaan akan mendapatkan kinerja karyawan yang optimal sesuai dengan standar yang ditentukan. Keinginan berprestasi diwujudkan melalui kerja yang baik dalam melaksanakan programprogram kerja yang telah ditetapkan.

Menurut (Hasibuan, 2012) seorang karyawan akan menghasilkan kinerja yang tinggi jika termotivasi dalam bekerja. Oleh karena itu tidaklah heran jika karyawan yang mempunyai motivasi kerja yang tinggi biasanya mempunyai kinerja yang tinggi pula. Salah satu indikator motivasi adalah dengan adanya kompensasi sehingga membuat karyawan bekerja lebih giat lagi.

Dugaan kuat yang menyebabkan rendahnya kinerja karyawan adalah kurang efektifnya kepemimpinan dan rendahnya motivasi kerja. Selain itu penyebab rendahnya kinerja adalah pembagian tugas yang terkadang tidak sesuai job description; tugas suatu bagian tidak dilaksanakan oleh bagian yang bersangkutan, tetapi dibebankan pada bagian lain yang membuat ada bagian atau karyawan yang harus bekerja ekstra sementara bagian lain bekerja lebih ringan.

Penilaian kinerja karyawan PT. Ambassador Zulias Kab.Wajo belum sepenuhnya diterapkan, belum adanya reward atas keberhasilan pencapaian target kinerja. Dalam hal ini peran pemimpin dan motivasi kerja sangat penting dalam meningkatkan kinerja karyawan untuk memberikan hasil pekerjaan yang maksimal.

Hasil penelitian terdahulu yang telah membuktikan bahwa motivasi kerja berpengaruh positif dan signifikan terhadap kinerja pegawai oleh (Nicolai \& Adrian, 2014), (Liana dan Irawati, 2014), (Azin \& Reihan, 2013), (Trisnowati, 2013), (Ronny \& Sudiro, 2014).

Budaya kerja adalah suatu falsafah dengan didasari pandangan hidup sebagai nilainilai yang menjadi sifat, kebiasaan dan juga pendorong yang dibudayakan dalam 
suatu kelompok dan tercermin dalam sikap menjadi perilaku, cita-cita, pendapat, pandangan serta tindakan yang terwujud sebagai kerja. Budaya kerja menurut Mangkunegara dalam (Assagaf, 2012) mendefinisikan bahwa budaya kerja adalah seperangkat asumsi atau sistem keyakinan, nilai-nilai dan norma yang dikembangkan dalam organisasi yang dijadikan pedoman tingkah laku bagi anggota-anggotanya untuk mengatasi masalah adaptasi eksternal dan integrasi internal.

Kondisi budaya kerja pada PT. Ambassador Zulias Kab.Wajo sangat memperihatinkan kuranganya kekompakan keselarasan dan kekeluargaan dalam melaksanakan tugasnya sebagai karyawan pada PT Ambassador Zulias Kab.Wajo. Berdasarkan definisi budaya kerja diatas dari para ahli dapat disimpulkan bahwa budaya kerja merupakan nilai-nilai atau kebiasaan yang dianut sebuah organisasi untuk menjadikan pedoman perusaahan demi mencapai tujuan yang akan dicapai oleh perusahaan.

Hasil penelitian terdahulu yang telah membuktikan bahwa budaya kerja berpengaruh positif dan signifikan terhadap kinerja karyawan adalah (Pradana, 2012), dan (Kusumawati, 2015)

Kinerja (Performance) adalah hasil kerja yang dapat dicapai oleh seseorang atau sekelompok orang dalam suatu organisasi, sesuai dengan wewenang dan tanggung jawab masing-masing, dalam rangka upaya mencapai tujuan perusahaan bersangkutan secara legal, tidak melanggar hukum dan sesuai dengan moral maupun etika. Disamping itu, kinerja (performance) diartikan sebagai hasil kerja seseorang karyawan, sebuah proses manajemen atau suatu organisasi secara keseluruhan, dimana hasil kerja tersebut harus dapat ditunjukkan buktinya secara konkrit dan dapat diukur (dibandingkan dengan standar yang telah ditentukan). Banyak sekali faktor-faktor yang mempengaruhi kinerja seorang karyawan, baik yang berasal dari karyawan itu sendiri atau dari luar diri karyawan tersebut. Faktor yang berasal dari diri pegawai adalah faktor-faktor internal yang meliputi kompetensi berdasarkan pengetahuan dan keterampilan, motivasi kerja, kepuasan kerja dan gaya kepemimpinan. Sedangkan faktor dari luar diri karyawan meliputi lingkungan kerja dan situasi kerja (Wibowo, 2013), beberapa di antara faktor yang mempengaruhi kinerja karyawan antara lain adalah motivasi, kompetensi dan lingkungan kerja karyawan.

Penilaian kinerja (Performance Appraisal) adalah suatu sistem yang digunakan untuk menilai dan mengetahui sejauh mana seorang karyawan telah melaksanakan pekerjaannya secara keseluruhan. Hal ini menunjukan bahwa PT. Ambassador Zulias Kab.Wajo memerlukan good management artinya harus mengembangkan Sumber Daya Manusia sebagai good manager dan organisasi yang baik, maka perlu menjadi perhatian bahwa kemampuan pemimpin dalam memimpin PT. Ambassador Zulias Kab.Wajo memberikan dampak bagi kinerja. Kepemimpinan yang diterapkan seorang pemimpin berbeda-beda sesuai dengan kebutuhan sehingga dapat mendorong para bawahannya untuk memberikan kontribusi yang terbaik kepada perusahaan, dengan adanya kepemimpinan yang efektif mampu meningkatkan kinerja karyawan. 
Dalam kaitannya dengan kinerja karyawan, hal tersebut tentunya harus segera dibenahi agar para pimpinan dan bawahan PT. Ambassador Zulias Kab.Wajo dapat memberikan kinerja yang maksimal kepada perusahaan secara lebih profesional. Penelitian ini dilakukan untuk mengetahui apakah kepemimpinan, motivasi dan budaya kerja mempunyai pengaruh signifikan terhadap kinerja karyawan dalam suatu perusahaan.

Berdasarkan fenomena di atas dan penelitian terdahulu, maka akan dilakukan penelitian dengan judul "Pengaruh Kepemimpinan, Motivasi Dan Budaya Kerja Terhadap Kinerja Karyawan PT. Ambassador Zulias Kab.Wajo".

Berdasarkan uraian tersebut, maka kerangka konseptual penelitian ini adalah:

\section{Gambar 1: Kerangka Konseptual}

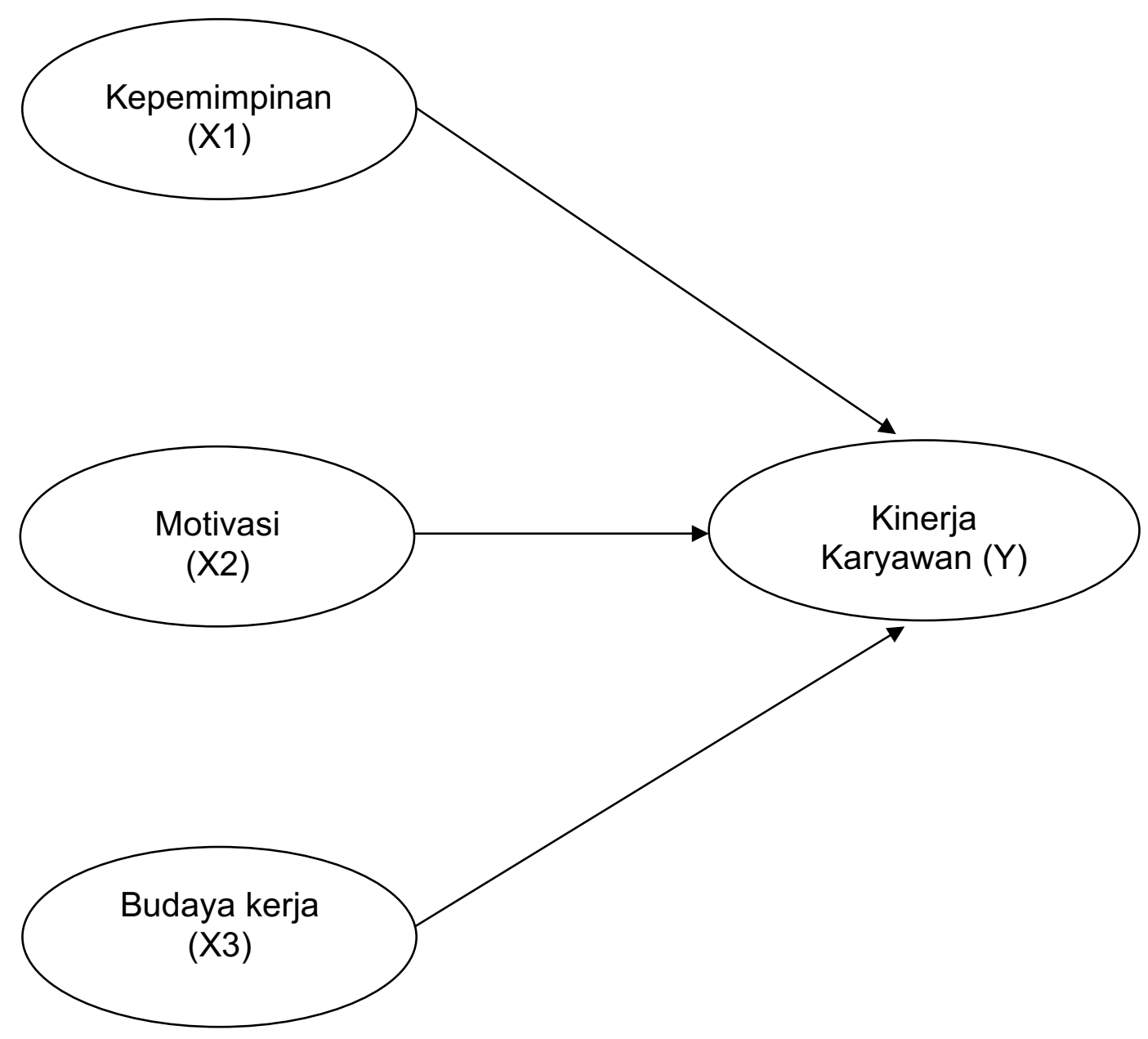

\section{Hipotesis}

Hipotesis yang akan di uji dalam penelitian ini dengan kerangka pemikiran dan hasil-hasil penelitian yang relavan di atas yaitu sebagai berikut: 
a. Kepemimpinan berpengaruh positif dan signifikan terhadap kinerja karyawan PT Ambasador Zulias Kab.Wajo.

b. Motivasi berpengaruh positif dan signifikan terhadap kinerja karyawan pada PT. Ambasador Zulias Kab.Wajo.

c. Budaya kerja berpengaruh positif dan signifikan terhadap kinerja karyawan pada PT. Ambasador Zulias Kab.Wajo.

\section{METODE PENELITIAN}

Pendekatan penelitian yang digunakan dalam penelitian ini adalah pendekatan kuantitatif dengan menggunakan jenis penelitian survey yaitu penelitian yang mengambil sampel dari populasi dengan menggunakan kuesioner sebagai alat pengumpulan data yang pokok. Populasi merupakan keseluruhan subyek yang diamati dalam suatu penelitian. Menurut (Sugiyono, 2011) "Populasi adalah wilayah generalisasi yang terdiri atas subjek atau objek yang mempunyai kualitas dan karakteristik tertentu yang ditetapkan oleh peneliti". Adapun menjadi populasi dalam penelitian ini adalah seluruh karyawan pada PT. Ambassador Zulias Kab.Wajo yaitu 33 orang. Menurut (Sugiyono, 2011) “Sampel adalah bagian dari jumlah dan karakteristik yang dimiliki oleh populasi". Melihat populasi yang tidak terlalu besar yaitu jumlahnya kurang dari seratus orang, maka penelitian ini menggunakan metode penelitian sensus. Sejalan dengan itu, menurut (Arikunto, 2006) menjelaskan bahwa jika jumlah populasi subjek kurang dari 100, maka semua anggota populasi dapat dijadikan sampel. Dengan demikian metode penarikan sampel yang digunakan adalah sampel jenuh atau metode sensus. Jadi sampel pada penelitian ini sebanyak 32 orang.

\section{Uji Hipotesis}

\section{a. Uji F (uji simultan)}

Uji F digunakan untuk mengetahui tingkat signifikan dari pengaruh variable independent secara serempak terhadap variable dependent. Uji dilaksanan dengan langkah membandingkan nilai $\mathrm{F}$ hitung dengan $\mathrm{F}$ tabel dengan kriterianya:

1. H0 diterima jika Fhitung < Ftabel atau nilai sig. $>0,05$ dimana variabel independent $(X)$ secara bersama-sama tidak memiliki pengaruh signifikan terhadap variabel dependent $(Y)$.

2. H0 ditolak (H1 diterima) jika $F$ hitung $>F$ tabel atau nilai sig. $<0,05$ dimana variabel independent $(X)$ secara bersama-sama memiliki pengaruh signifikan terhadap variabel dependent $(Y)$.

\section{b. Uji t (uji parsial)}

Uji $t$ digunakan untuk menguji tingkat signifikan dari pengaruh variable independent secara parsial terhadap variabel dependent. Uji dilaksanakan dengan langkah membandingkan nilai Thitung dengan $t$ tabel kriteria: 
1. H0 diterima jika $\mathrm{t}$ hitung $<\mathrm{t}$ tabel atau nilai sig. $>0,05$ dimana variabel independent $(X)$ secara individual tidak memiliki pengaruh signifikan terhadap variabel dependent $(\mathrm{Y})$

2. H0 ditolak (H1 diterima) jika $\mathrm{t}$ hitung $>\mathrm{t}$ tabel atau nilai sig. $<0,05$ dimana variabel independent $(X)$ secara individual memiliki pengaruh signifikan terhadap variabel dependent $(Y)$.

\section{HASIL PENELITIAN DAN PEMBAHASAN}

\section{Hasil}

Untuk mengetahui pengaruh variabel kepemimpinan (X1), motivasi, (X2), dan budaya kerja kerja (X3), terhadap kinerja karyawan PT. Ambassador Zulias Kab.Wajo dapat dilihat pada tabel 1 berikut ini:

Tabel 1: Data regresi berganda mengenai pengaruh kepemimpinan, motivasi dan budaya kerja terhadap kinerja karyawan pada PT. Ambassador Zulias Kab.Wajo.

\section{Coefficients ${ }^{a}$}

\begin{tabular}{|c|c|c|c|c|c|c|}
\hline \multirow{2}{*}{\multicolumn{2}{|c|}{ Model }} & \multicolumn{2}{|c|}{$\begin{array}{l}\text { Unstandardized } \\
\text { Coefficients }\end{array}$} & \multirow{2}{*}{ 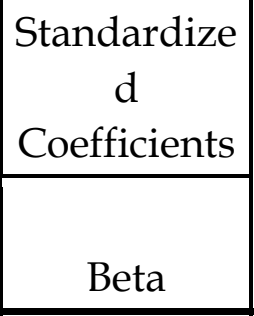 } & \multirow[b]{2}{*}{$\mathrm{t}$} & \multirow[b]{2}{*}{ Sig. } \\
\hline & & B & Std. Error & & & \\
\hline 1 & (Constant & 2,803 & 1,184 & & 2,369 & ,025 \\
\hline & $\mathrm{X} 1$ & 153 & ,055 & ,437 & 3,793 & ,009 \\
\hline & $\mathrm{X} 2$ & ,167 & ,040 & ,243 & 2,705 & 099 \\
\hline & X3 & 102 & ,054 & ,277 & 2,890 & ,069 \\
\hline
\end{tabular}

a. Dependent Variable: $Y$

Sumber: Data diolah, 2020

Pada tabel 1 diatas dketahui nilai konstanta yaitu $\beta_{0}=2,803$, variabel kepemimpinan $(\beta 1)$ sebesar 0,153 , variabel motivasi $(\beta 2)$ sebesar 0,167 , variabel budaya kerja $(\beta 3)$ sebesar 0,102. Adapun bentuk persamaan regresi sebagai berikut:

$$
Y=2,803+0,153 X_{1}+0,167 X_{2}+0,102 X_{3}
$$

a. Nilai konstan yaitu $\beta_{0}=2,803$, mempunyai arti bahwa, apabila variabel kepemimpinan $(\beta 1)$ sebesar 0,153 , variabel motivasi sebesar $(\beta 2) 0,167$, budaya kerja ( $\beta 3$ ) sebesar 0,102 tidak mengalami perubahan, maka kinerja karyawan sebesar 2,803.

b. $\beta 1$ sebesar 0,153 artinya jika variabel independen motivasi ( $\beta 2$ ) dan variabel budaya kerja ( $\beta 3$ ) tetap dan variabel kepemimpinan ( $\beta 1)$ meningkat, maka kinerja karyawan PT. Ambassador Zulias Kab.Wajo akan mengalami peningkatan, koefisien bernilai positif artinya terjadi hubungan positif antara 
kepemimpinan dengan kinerja karyawan PT. Ambassador Zulias Kab.Wajo. Semakin meningkat kepemimpinan maka semakin meningkat pula kinerja karyawan.

c. $\beta 2$ sebesar 0,167 , artinya jika variabel independen kepemimpinan $(\beta 1)$ dan variabel budaya kerja ( $\beta 3)$ tetap dan variabel motivasi $(\beta 2)$ meningkat, maka kinerja karyawan PT. Ambassador Zulias Kab.Wajo akan mengalami peningkatan, koefisien bernilai positif artinya terjadi hubungan positif antara motivasi dengan kinerja karyawan PT. Ambassador Zulias Kab.Wajo Semakin meningkat motivasi maka semakin meningkat pula kinerja karyawan.

d. $\beta 3$ sebesar 0,102 , artinya jika variabel independen kepemimpinan ( $\beta 1)$ dan variabel motivasi ( $\beta 2$ ) tetap dan variabel budaya kerja $(\beta 3)$ meningkat, maka kinerja karyawan PT. Ambassador Zulias Kab.Wajo akan mengalami peningkatan, koefisien bernilai positif artinya terjadi hubungan positif antara budaya kerja dengan kinerja karyawan PT. Ambassador Zulias Kab.Wajo. Semakin meningkat motivasi kerja maka semakin meningkat pula kinerja.

Hasil pengujian secara parsial pada tabel 1 dapat diuraikan sebagai berikut:

a. Variabel kepemimpinan terhadap kinerja karyawan

Berdasarkan hasil penelitian yang menguji pengaruh kepemimpinan terhadap kinerja karyawan nilai $\mathrm{t}$ hitung $=3,793>\mathrm{t}$ tabel $=1,701$ dengan tingkat signifikan sebesar $=0,009<a=0,05(5 \%)$. Hasil ini menunjukkan bahwa secara perhitungan statistik kepemimpinan berpengaruh positif dan signifikan terhadap kinerja karyawan PT. Ambassador Zulias Kab.Wajo.

b. Variabel motivasi terhadap kinerja karyawan

Berdasarkan hasil penelitian yang menguji pengaruh motivasi terhadap kinerja karyawan nilai $\mathrm{t}$ hitung $=2,705>\mathrm{t}$ tabel $=1,701$ dengan tingkat signifikan sebesar $=0,099>a=0,05(5 \%)$. Hasil ini menujukkan bahwa secara perhitungan statistik motivasi berpengaruh negatif dan tidak signifikan terhadap kinerja karyawan PT. Ambassador Zulias Kab.Wajo.

c. Variabel budaya kerja terhadap kinerja karyawan

Berdasarkan hasil penelitian yang menguji pengaruh budaya kerja terhadap kinerja karyawan nilai $\mathrm{t}$ hitung $=2,890>\mathrm{t}$ tabel $=1,699$ dengan tingkat signifikan sebesar $=0,069>a=0,05(5 \%)$. Hasil ini menujukkan bahwa secara perhitungan statistik budaya kerja berpengaruh negatif dan tidak signifikan terhadap kinerja karyawan PT. Ambassador Zulias Kab.Wajo.

Pengujian secara simultan atau serempak bertujuan untuk mengetahui pengaruh variabel kepemimpinan (X1), motivasi (X2), dan budaya kerja (X3) terhadap kinerja karyawan PT. Ambassador Zulias Kab.Wajo Dapat dilihat pada tabel 2 berikut ini: Tabel 2: Hasil pengujian secara simultan (uji-F) 


\begin{tabular}{|c|c|c|c|c|c|c|}
\hline & Model & $\begin{array}{l}\text { Sum of } \\
\text { Squares }\end{array}$ & Df & $\begin{array}{l}\text { Mean } \\
\text { Square }\end{array}$ & $\mathrm{F}$ & Sig. \\
\hline \multirow[t]{3}{*}{1} & Regression & 9,179 & 3 & \multirow{3}{*}{$\begin{array}{r}3,060 \\
, 315\end{array}$} & \multirow[t]{3}{*}{9,712} & \multirow[t]{3}{*}{, $000^{\mathrm{b}}$} \\
\hline & Residual & 8,821 & 28 & & & \\
\hline & Total & 7,835 & 32 & & & \\
\hline
\end{tabular}

a. Predictors: (Constant), X3, X2, X1

b. Dependent Variable: $Y$

Sumber: Data diolah, 2020

Tabel 2 diatas diperoleh $\mathrm{F}$ hitung $=9,712>\mathrm{F}$ tabel $=2,95$ serta memiliki tingkat signifikan 0,000. Karena probabilitas 0,000<0,05 (5\%) maka dapat dikatakan bahwa model regresi yang telah digunakan dapat meningkatkan kinerja karyawan atau kepemimpinan (X1), motivasi (X2), dan budaya kerja (X3) secara bersama-sama berpengaruh terhadap kinerja karyawan. Hipotesis yang menyatakan bahwa kepemimpinan, motivasi dan budaya kerja berpengaruh positif dan signifikan terhadap kinerja karyawan PT. Ambassador Zulias Kab.Wajo.

\section{PEMBAHASAN}

Berdasarkan hasil analisis data, baik dengan menggunakan analisis deskriptif maupun menggunakan regresi linier berganda, maka selanjutnya dilakukan pembahasan setiap indikator pengaruh X1, X2, X3 (kepemimpinan, motivasi, dan budaya kerja) terhadap indikator variabel terikat $Y$ (kinerja karyawan) PT. Ambassador Zulias Kab.Wajo sebagai berikut:

\section{Pengaruh Kepemimpinan Terhadap Kinerja Karyawan}

a. Semakin tinggi tanggung jawab seorang pemimpin dalam suatu perusahaan dalam pekerjaan maka karyawan akan termotivasi meningkatkan kualitas dan kuantitas kinerja dalam hal ini sebagai bentuk bahwa karyawan merasa memiliki tanggung jawab yang besar terhadap kualitas dan kuantitas pekerjaan jika seorang pemimpin memberikan panutan terhadap karyawan.

b. Sikap percaya diri seorang pemimpin memberikan arahan tentang pekerjaan kepada karyawan akan membuat karyawan mengerti tentang pekerjaan yang menjadi tanggung jawab sehingga karyawan dengan mudah menyelesaikan setiap pekerjaan yang diberikan.

c. Pemimpin yang memiliki komitmen dalam peningkatan pencapaian kinerja akan menjadikan karyawan meningkatkan dan memaksimalkan kemampuan agar kualitas dan kuantitas kinerja dapat tercapai.

d. Tindak tegas seorang pemimpin akan membuat karyawan memiliki inisiatif membangun kerjasama untuk dapat menyelesaikan pekerjaan tepat waktu dan lebih meningkatkan kualitas dan kuantitas kerja.

e. Pemimpin yang membangun hubungan baik dengan bawahan akan menimbulkan rasa kebersamaan dan kenyamanan terhadap karyawan 
sehingga pencapaian kualitas dan kuantitas kinerja tidak menjadi beban kepada karyawan.

Menurut Thoha (2017) kepemimpinan adalah kegiatan untuk mempengaruhi perilaku orang lain atau seni mempengaruhi perilaku manusia baik perorangan maupun kelompok.

Hal ini menunjukkan kepemimpinan merupakan cerminan bahwa keberhasilan suatu perusahaan dalam menjalankan aktivitasnya sangat ditentukan oleh keberadaan pemimpinnya. Juga berkaitan dengan penelitian Helena Nataly Tapoona (2014) Tujuan dari penelitiaan adalah untuk menganalisis pengaruh kepemimpinan, motivasi kerja, dan budaya organisasi pada komitmen organisasi dan kinerja pegawai di institusi perguruan tinggi. Sampel penelitian terdiri dari 136 responden, yang merupakan pegawai STEM Akamigas Cepu, yang diambil dengan menggunakan teknik purposive sampling. Data dianalisis dengan analisis regresi linear berganda menggunakan program SPSS dan analisis jalur. Hasil penelitian menunjukkan bahwa kepemimpinan, motivasi kerja, dan budaya organisasi berpengaruh langsung signifikan pada komitmen organisasi; kepemimpinan, motivasi kerja, dan budaya organisasi berpengaruh tidak langsung signifikan pada kinerja pegawai melalui komitmen organisasi sebagai variabel interverning; dan komitmen organisasi berpengaruh langsung signifikan pada kinerja pegawai.

\section{Pengaruh motivasi Terhadap Kinerja Karyawan}

a. Motivasi yang diberikan pimpinan akan membangun semangat kerja karyawan dan memacu dirinya mencapai prestasi dalam kinerja.

b. Kebutuhan pengakuan juga sangat dibutuhkan oleh karyawan dimana karyawan mengharapkan posisi sesuai dengan kemampuan mereka dalam bekerja.

c. Penghargaan atas prestasi kerja yang diberikan oleh perusahaan akan menambah semangat kerja karyawan dikarenakan penghargaan terkadang dalam bentuk promosi jabatan yang otomatis segala bentuk kompensasi yang akan didapatkan juga meningkat sehingga menjadikan karyawan akan memaksimalkan kualitas dan kuantitas kinerja untuk bias mendapatkan penghargaan tersebut.

d. hubungan baik dengan sesama karyawan akan menimbulkan rasa kebersamaan dan kenyamanan terhadap karyawan sehingga pencapaian kualitas dan kuantitas kinerja tidak menjadi beban kepada karyawan.

e. Karyawan akan memiliki prinsip bahwa dengan kualitas dan kuantitas kinerja yang dihasilkan karyawan akan meraih segala bentuk penghargaan yang diberikan perusahaan sebagai pengaktualisasian diri.

Motivasi dapat dilihat dari sikap karyawan bekerja dengan sungguh-sungguh untuk memperbaiki kinerja masa lalu, karyawan diharapkan dapat menunjukkan prestasi dan perusahaan menyediakan sistem promosi jabatan sebagai pengakuan kinerja yang tercapai.

Menurut (Chukwuma \& Obiefuna, 2014) menjelaskan bahwa "Motivasi adalah proses membangkitkan perilaku, mempertahankan kemajuan perilaku dan 
menyalurkan perilaku tindakan yang spesifik. Dengan demikian, motif (kebutuhan, keinginan) mendorong karyawan untuk bertindak.

Hasil penelitian ini tidak sejalan dengan penelitian (Agusta, 2013) menyatakan bahwa motivasi mempunyai pengaruh positif dan signifikan terhadap kinerja karyawan.

Dapat disimpulkan bahwa PT. Ambassador Zulias Kab. Wajo belum memaksimalkan motivasi dan apresiasi untuk kinerja karyawan sehingga tidak memberikan dorongan kepada karyawan semakin meningkatkan kinerja.

\section{Pengaruh Budaya KerjaTerhadap Kinerja Karyawan.}

a. Kebebasan berinovasi karyawan yang diberikan perusahaan membuat karyawan dapat menerapkan keahliannya dalam kinerja untuk memajukan perusahaan.

b. Toleransi terhadap perbedaan pendapat sesama karyawan akan membuat karyawan tidak terbebani dalam menyampaikan setiap pendapat untuk perubahan strategi kerja untuk mencapai tujuan perusahaan.

c. Karyawan yang merasa dihargai dengan setiap inisatif yang mereka lakukan akan selalu memiliki tanggung jawab secara individu untuk terus berinovasi dalam kinerja.

d. Imbalan yang diterima oleh karyawan dari perusahaan sebagai bentuk bahwa kualitas kinerja sangat dibutuhkan untuk kemajuan perusahaan sehingga karyawan senantiasa memberikan hasil kinerja yang maksimal.

e. Karyawan akan termotivasi dalam meningkatkan kinerja jika perusahaan mengapresiasi tindak agresif mereka dalam memajukan perusahaan.

Menurut Mangkunegara dalam (Assagaf, 2012) mendefinisikan bahwa budaya kerja adalah seperangkat asumsi atau sistem keyakinan, nilai-nilai dan norma yang dikembangkan dalam organisasi yang dijadikan pedoman tingkah laku bagi anggota-anggotanya untuk mengatasi masalah adaptasi eksternal dan integrasi internal.

Hasil peneltian ini tidak sejalan dengan peneltian Monce Brury (2016) menjelaskan bahwa budaya organisasi berpengaruh signifikan terhadap kinerja karyawan.

Dapat dinilai bahwa budaya kerja berupa toleransi, kebebasan berinovasi dan sebagainya hanya berlaku kepada karyawan lama sehingga karyawan baru merasa terbatasi dengan kontribusi yang akan diberikan untuk meningkatkan kinerja mereka.

\section{KESIMPULAN}

Berdasarkan hasil penelitian dan pembahasan, maka dapat ditarik kesimpulan sebagai berikut:

1. Variabel kepemimpinan berpengaruh positif dan signifikan terhadap kinerja karyawan PT. Ambassador Zulias Kab. Wajo.

2. Variabel motivasi berpengaruh negatif dan tidak signifikan terhadap kinerja karyawan PT. Ambassador Zulias Kab. Wajo.

3. Variabel budaya kerja berpengaruh negatif dan tidak signifikan terhadap 
kinerja karyawan PT. Ambassador Zulias Kab. Wajo.

\section{DAFTAR PUSTAKA}

Agusta, L. (2013). Pengaruh Pelatihan dan Motivasi Kerja Terhadap Kinerja Karyawan CV Haragon Surabaya. Agora, 1(13), 1399-1408)

Arikunto. (2006). Prosedur Penelitian Suatu Pendekatan Praktek. Jakarta: PT. Rineka Cipta.

Assagaf. Y. (2012). Pengaruh Budaya Kerja Terhadap Kinerja Karyawan Pada PT. Hadji Kalla Cabang Alauddin Makasar., Skripsi. Jurusan Ekonomi dan Bisnis Fakultas Manajemen Universitas Hasanuddin.

Brury, M. (2016). Pengaruh Kepemimpinan, Budaya Organisasi, Motivasi Kerja dan Kepuasan Kerja Terhadap Kinerja Pegawai Pada Kantor SAR Sorong. Jurnal Riset Bisnis dan Manajemen. Vol 4 No.1. Program Magister Manajemen Fakultas Ekonomi dan Bisnis. Universitas Sam Ratulangi

Chukwuma, E.M., \& Obiefuna, O. (2014). Effect of Motivation on Employee Productivity: A Study of Manufacturing Companies in Nnewi. Journal of Managerial Studies and Research 2 (7).

Hasibuan, M. (2012). Manajemen Sumber Daya Manusia. PT. Bumi Aksara, Jakarta.

Hasibuan, SP. (2015). Manajemen Sumber Daya Manusia. Penerbit: Bumi Aksara. Jakarta.

Kusumawati, R.W. (2015). Pengaruh Budaya Kerja dan Semangat Kerja Terhadap Kinerja Karyawan Bank Mandiri KCP Puger Jember. Jurnal Fakultas Ekonomi Universitas Muhammadiyah Jember; Desember 2015.

Pradana, R.M. G.R. (2012) Pengaruh Budaya Kerja Terhadap Kinerja Karyawan di Koperasi Karyawan Redrying Bojonegoro (Kareb). Universitas Brawijaya. Fakultas Ekonomi.

Priatna. C. (2015), Perilaku Organisasi. PT. Remaja Rosdakarya, Bandung.

Rivai, V. (2013). Manajemen Sumber Daya Manusia Untuk Perusahaan Dari Teori Ke Praktek. Rajagrafindo persada, Bandung.

Sugiyono. (2011). Metode Penelitian Kuantitatif dan Kualitatif dan R \& D. CV Alfabeta : Bandung.

Sutikno, S. M. (2014). Pemimpin Dan Gaya Kepemimpinan, Edisi Pertama Lombok: Holistica.

Tapoona, H.N. (2014). Pengaruh Kepemimpinan, Budaya Organisasi, Motivasi Terhadap Kepuasan Kerja Karyawan serta Dampaknya terhadap Kinerja Organisasi di Unika Atma Jaya. Universitas Terbuka. Program Pascasarjana. Magister Manajemen.

Thoha, M. 2017. Kepemimpinan dalam Manajemen. Jakarta: PT. Raja Grafindo Persada. 
Pengaruh Kepemimpinan, Motivasi, (Sirajuddin, Mus \& Arfah) | 238

Wibowo, 2013. Manajemen Kinerja, Cetakan Keenam. Penerbit PT. Rajagrafindo Persada, Jakarta 